\title{
SENI BUDAYA SEBAGAI UPAYA PEMBELAJARAN PENDIDIKAN AGAMA ISLAM BERNILAI ESTETIKA
}

\author{
Mizan Khairusani ${ }^{1}{ }^{*}$ \\ 1 Program Studi Pendidikan Agama Islam \\ Universitas Islam Negeri Sunan Kalijaga, Yogyakarta \\ *E-mail: mizankhairusan@gmail.com
}

\begin{abstract}
Education is a cultural process, in which education will greatly affect human continuity in religion, socialization and culture. Education and cultural arts can never be separated because they influence each other, including cultural arts that shape the personality of an individual or group. Therefore, the process in education must have high-cultured wisdom in order to build attitudes, a balanced character of students from cognitive, affective, psychomotor results. More specifically, the purpose of Islamic education is to build character and good character. It is felt that Islamic education which is full of the meaning and beauty of God will be easily combined with elements of art and culture. Armed with this art and culture, an educator will be able to create an innovative, creative, fun learning process, because the learning has aesthetic values.
\end{abstract}

Keywords: Art and Culture, Islamic Education, Aesthetic Values

\begin{abstract}
Abstrak
Pendidikan merupakan sebuah proses kultural, di mana pendidikan akan sangat berpengaruh bagi kelangsungan manusia dalam beragama, bersosial maupun berbudaya. Pendidikan dan seni budaya tidak akan pernah bisa dilepaskan karena kuduanya saling mempengaruhi, termasuk seni budaya yang membentuk kepribadian suatu individu maupun kelompok. Karenanya proses di dalam pendidikan harus memilki kearifan yang berbudaya luhur guna membangun sikap, karakter peserta didik yang seimbang dari hasil kognitif, afektif, psikomotorik. Lebih khusus tujuan pendidikan agama Islam dalam membangun karakter, maupun budi pekerti yang baik. Pendidikan Agama Islam yang sarat akan makna dan keindahan-keindahan Tuhan dirasa akan mudah dipadukan dengan unsur-unsur seni dan budaya. Dengan berbekal seni dan budaya tersebut, seorang pendidik akan mampu menciptakan proses pembelajaran yang inovatif, kreatif, menyenangkan, karena pembelajaran tersebut memiliki nilai-nilai keestetikaan.
\end{abstract}

Kata Kunci: Seni Budaya, Pendidikan Agama Islam, Nilai Estetika

\section{PENDAHULUAN}

Kesenian atau seni budaya merupakan suatu ekspresi bagi tiap-tiap individu maupun kelompok, baik itu ekspresi jiwa, kepercayaan, ataupun ekpresi dari hasil pemikiran. Misalnya ekspresi seseorang terhadap agama berupa candi, kisah-kisah epik orang-orang dahulu yang sarat makna, tari-tarian sufi, aransemen musik, tulisantulisan kaligrafi dan lain sebagainya, itu semua adalah nilai estetika yang mahal harganya. 
Dalam buku H.A.R Tilaar Pendidikan Kebudayaan, para ahli pendidikan dan antropologi sepakat bahwa seni budaya merupakan dasar terbentuknya kepribadian manusia, darinya terbentuk identitas seseorang, identitas masyarakat ataupun identitas suatu bangsa (Tilaar,2002). Seni merupakan bagian dari kehidupan yang bertujuan sama dengan tujuan hidup. Tujuan hidup dari orang beragama adalah kebahagiaan spiritual dan material di dunia maupun di akhirat serta menjadi rahmat bagi segenap alam di bawah naungan keridhaan Tuhan.

Dalam konteks agama Islam, seni merupakan media untuk mensyukuri nikmat Allah SWT telah memberikan potensi rohani maupun indrawi kepada manusia, dan fungsi seni adalah untuk menghayati sepuhan Allah SWT, baik yang terlihat di alam maupun pada kreasi atau hasil cipta manusia (Nur Ana, 2018).

Al-Qur'an memandang seni budaya sebagai suatu proses dan merupakan eksistensi manusia dalam hidupnya. Seni budaya tidak lepas dari nilai-nilai kemanusiaan, namun seni bisa lepas dari nilai-nilai ketuhanan. Seni budaya Islam adalah hasil dari akal, budi, cipta rasa, karsa manusia yang dilandasi nilai ketauhidan. Hasil cipta manusia tersebut akan terseleksi oleh nilai-nilai kemanusiaan yang bersifat universal, kemudian berkembang manjadi peradaban yang dimiki oleh individu maupun kelompok (Saidah, 2008).

Berdasarkan pemisahan seni dan pendidikan akan ada satu unsur saja di dalam kebudayaan atau seni budaya, dengan demikian pendidikan bukan merupakan tempat berkembangnya kebudayaan yang pada dasarnya pendidikan merupakan bagian yang tidak terpisahkan dari kebudayaan. Hal tersebut karena beberapa gejala di antaranya adalah : pertama, budaya telah dibatasi pada hal-hal yang berkenaan dengan kesenian saja, kedua, nilai-nilai kebudayaan di dalam pendidikan hanya menekankan pada ranah intelektual, dan ketiga, nilai-nilai agama masih memberatkan pada lembaga-lembaga agama saja (saidah, 2008).

Seni budaya sebagai sebuah proses, maka seni budaya tentu sangat berkaitan dengan pendidikan, melihat pendidikan adalah bagaian dari pembudayaan yang berujung pada peradaban. Ada beberapa alasan mengenai seni budaya bagi dunia pendidikan menjadi penting, mengutip dari Nur Saidah, di antaranya : Pertama di era modern ini masih saja ada orang yang menyempitkan makna dari seni budaya, masih ada yang belum mengetahui seutuhnya, bahkan bagaimana memahami urgensinya seni di dalam dunia pendidikan. Dalam artian seni budaya masih dianggap bagian yang 
terpisah dari proses pendidikan, memandang seni hanya sebatas nilai-nilai estetika. Kedua, melihat realitas proses pendidikan di Indonesia dewasa ini dirasa sangat intelektualitis, lebih mengedepankan nilai kognitif, dengan demikian dirasa sudah menjauh dari ajaran-ajaran yang pernah diajarkan leluhur umat manusia, terutama di dunia Islam termasuk juga ajaran-ajaran di Nusantara melaui kesenian. Ketiga, nilai estetika yang melekat kuat di dalam kesenian, estetika sendiri mampu menarik perhatian banyak orang karena mengandung unsur-unsur yang bisa dilihat, dirasakan dan diperdengarkan. Sama halnya dengan seni mendidik yang harus memiliki nilainilai estetika agar bisa direspons dengan baik, membudaya, mudah tersampaikan, dipahami serta diamalkan oleh seseorang yang menerima pengajaran (Saidah, 2008).

Melihat realitas dunia pendidikan, di dalam lembaga-lembaga formal masih terdapat keajekan atau stagnasi nilai-nilai estetika dalam upaya proses pembelajarannya, meskipun kurikulum terus diperbaharui dengan kesesuaian zaman. Nilai estetika yang dimaksud adalah nuansa berkesenian dan berkebudayaan di dalam proses pembelajaran. Alangkah indahnya jika unsur seni dan budaya melekat erat di dunia pendidikan formal.

Dewasa ini kata seni tidak hanya sebuah karya yang hanya bisa dinikmati saja, akan tetapi seni memiliki beberapa fungsi, di antaranya: fungsi religi, komunikasi, pendidikan, hiburan, artistik, kesehatan dan lain sebagainya. Dalam dunia pendidikan, seni akan memerikan pengaruh penting terhadap perkembangan mental maupun fisik perserta didik, dikarenakan seni dapat mengenalkan nilai-nilai dan norma-norma yang ada baik agama maupun masyarakat (Suhaya, 2016).

Dari ulasan di atas maka akan telihat urgensi seni budaya bagi pendidikan dan pendidikan bagi kelangsungan seni budaya dalam mewujudkan peradaban agar bernilai estetika. Korelasi keduanya akan berdampak bagi pendidik maupun peserta didik. Melihat di lapangan seorang pendidik harus terkesan menarik dan berwibawa dimata peserta didik. Begitupun peserta didik dirasa akan dimudahkan dan menghadirkan suasana menyenangkan (estetika) dalam proses pembelajaran dalam penanaman nilai-nilai yang diajarkan oleh seorang pendidik. Terkhusus pendidikan agama Islam yang sarat akan makna, tidak cukup hanya seabatas ilmu pengetahuan, melainkan nilai-nilai agama Islam harus tertanam dikehidupan sehari-hari.

Artikel ini berupaya mengupas lebih lanjut tentang interaksi seni budaya dengan pendidikan agama Islam upaya pengajaran bernilai estetika, apa kontribusi timbal 
balik di antara pendidikan agama Islam dengan perkermbangan seni budaya. Melihat realitasnya akan sangat mudah dan menyenangkan apabila suatu proses pembelajaran maupun peradaban untuk bisa dilakukan, dipahami dan dihayati dengan penuh keestetikaan.

\section{METODE PENELITIAN}

Untuk dapat memetakan dengan baik permasalahan dan fokus, penulis menggunakan metode penelitian library research atau kepustakaan. Pengumpulan data dilakukan dengan menelaah dan mengeksplorasi beberapa jurnal, artikel, buku dan dokumen yang berbentuk cetak maupun elektrinik dan sumber-sumber data atau informasi lainnya yang dianggap relavan dengan kajian. Dari data-data tersebut diolah dan di kembangkan menjadi sebuah wacana baru.

\section{HASIL DAN PEMBAHASAN}

\section{Pengembangan Seni Budaya dalam Pendidikan Agama Islam}

Seni (latin $=$ Ars) yang berarti keahlian, keahlian mengekspresikan ide-ide estetika, mewujudkan kemampuan imajinaasi kedalam karya yang menimbulkan rasa indah, menghasilkan bentuk kreasi bisa berupa lukisan, patung, tarian, syair dan lain sebagainya. Seni sendiri secara keseluruhan dibagi menjadi dua, yaitu pertama, seni murni, yaitu seni yang merujuk pada estetika atau keindahan semata, kedua seni budaya, yaitu berkenaan dengan keahlian untuk menghasilkan sesuatu dalam bentu tulisan, percakapan, dan benda bermanfaat yang indah (perpaduan estetika dengan kegunaan faedah), seperti hasil kerajinan tembikar, kerajinan logam, arsitektur, percakapan adat istiadat dan lain sebagainya (Ensiklopedia nasional, 1989).

Para ahli pendidikan dan antropologi menyepakati bahwa seni budaya adalah dasar terbentuknya kepribadian manusia. Maka dari seni budaya akan terbentuk identitas seseorang, identitas suatu masyaraat dan identitas suatu bangsa (Tilaar, 2002). Seni budaya adalah fitrah, kemampuan berseni dan berbudaya merupakan salah satu perbedaan manusia dengan makhluk lain. Jika demikian, Islam sebagai agama fitrah akan mendukung seni budaya selama penampilan lahir dan mendukung fitrah manusia yang suci, dan karena itu pula Islam bertemu dengan seni budaya dan jiwa manusia, sebgaimana seni budaya ditemukan oleh jiwa manusia dalam Islam (Leaman, 2005). 
Selain pembentukan kepribadian manusia, peran pendidikan seni budaya adalah sebagai pembentukan pribadi serta pengembangan potensi. Pembentukan pribadi bagi peserta didik maupun manusia pada umumnya, pembentukan pribadi yang harmonis dengan mempertimbangkan kebutuhan perkembangan anak didik untuk mencapai multi kecerdasan baik secara interpersonal, intrapersonal, visual, spasial, musika, matematik, linguistik, logic, naturalis, spriritual, religius, emosional, moral dan lain sebagainya.

Seni sebagai pengembangan dan aktualisasi potensi diri dimaksudkan dengan adanya fitrah manusia, maka seni sebagai keindahan adalah suatu kefitrahan yang dimiliki manusia. Oleh karena itu potensi tersembunyi yang ada pada manusia dapat diaktualisasikan dalam kehidupan, di mana potensi-potensi itu digunakan agar bermanfaat bagi manusia dan seluruh alam.

Budaya sebagai pembentukan sikap erat kaitannya dengan pendidikan agama Islam. Lembaga pendidikan Islam merupakan sarana pengembangan kepribadian peserta didik dan memiliki tanggung jawab intuk menyeimbangkan aspek kognitiflogika dengan aspek etika-estetika yaitu penyeimbangan otak bagian kanan dan kiri. Artinya pendidikan agama dan pendidikan ilmu umum haruslah seimbang.

Tujuan pendidikan dalam upayanya mengolah kepribadian anak didik banyak sedikitnya akan dibiasakan dengan berperilaku baik, didasari kepribadian yang baik serta mandiri. Menurut Sindhunata, salah satu cara dalam membentuk anak didik agar mandiri dan memiliki kepribadian dengan memperkenalkan mereka pada seni budaya. Artinya kesenian dan kebudayaan penting bagi peserta didik dalam pertumbuhan jiwa serta pikirannya.

Perasaan manusia menjadi tak terasah bila tanpa pengalaman keindahan (estetika) suatu karya seni dan kearifan serta kedalaman makna nilau-nilai suatu budaya. Melalui pendidikan seni dan budaya peserta didik akan terolah rasa, dan kemampuan mengolah rasa mamu menjadi sumber pengendalian diri (Sindhunata, 2000). Nilai-nilai seni budaya Islam sangat jelas dapat diintegrasikan dalam pendidikan agama Islam (PAI) yang tentunya berperan dalam mengembangkan aspek kognitif, afektif, maupun psikomotorik, di antara ketiganya haruslah seimbang antara pengembangan kemampuan otak, kemampuan otot dan rasa atau hati. 


\section{Hubungan Seni budaya dengan Pendidikan Agama Islam}

Agama dan kebudayaan adalah dua hal yang saling berinteraksi dan saling mempengaruhi, karena pada keduanya terdapat nilai dan simbol. Agama mempengaruhi kebudayaan atau seni budaya dalam pembentukannya, sedangkan seni budaya dapat mempengaruhi sistem nilai dan simbol agama.

Agama dalam perspektif ilmu-ilmu sosial adalah sebuah sistem nilai yang memuat sejumlah konsepsi mengenai konstruksi realitas, yang berperan besar dalam struktur tata normatif dan sosial. Sedangkan budaya merupakan ekspresi cipta, karya, dan karsa manusia (dalam masyarakat tertentu) yang mengandung nilai-nilai religiusitas, filosofis, dan kearifan lokal (local wisdom).

Melalui pendidikan dan seni budaya maka dirasa peserta didik akan menjadi mandiri dan percaya diri, dikarenakan kesenian berperan bagi pertumbuhan pemikiran dan jiwa seseorang. Seni budaya mampu mengasah perasaan dan pemaknaan suatu makna seseorang melalui keindahan dari hasil cipta manusia. Penguatan mengolah rasa ini menjadi dasar bagi peserta didik untuk mengendalikan diri.

Sesuai dengan tujuan pendidikan yang berkenaan dengan kognitif, afektif maupun psikomotoriknya, artinya di antara pencapaian ketiganya harus seimbang. Nilai-nilai seni budaya dapat mengembangkan ketiga aspek tersebut, terutama seni budaya Islam. Pertama, dengan cara mengkritisi suatu karya, ini berkenaan dengan kognitif, kedua, bisa mengapresiasi, menghormati suatu karya, mengapresiasi ini berkenaan dengan olah rasa, ketiga mengamalkan nilai-nilai yang terkandung di dalam suatu karya, bahkan bisa untuk mengembangkan suatu karya tersebut.

Terdapat banyak karya seni yang tercipta di dunia ini, baik oleh individu-individu atau seni yang lahir dari suatu kebudayaan. Salah satunya adalah seni sastra. Kajian sastra menjadi penting untuk memahami hubungan antara seni dan agama Islam. Karena ajaran Islam berdasarkan pada firman Allah SWT yang diwahyukan berupa kitab suci, maka sastra menjadi bagian penting dan istimewa di antara berbagai bentuk seni Islam lainnya (Nasr, 1993).

Dalam pengajarannya jika melalui beberapa syair, musik, budaya lokal dan sebagainya dirasa akan efektif untuk meningkatkan rasa dalam beragama. Tidak heran jika lembaga-lembaga pendidikan agama dewasa ini banyak memperhatikan dan 
menyelenggarakan kegiatan-kegiatan yang arahnya berkeseian dan berkebudayaan upaya untuk sarana pembelajaran pereseta didiknya.

\section{Pendidikan Agama Islam dalam Pengembangan Seni Budaya Islam}

Agama dan kehidupan manusia pada dasarnya memiliki sumber yang sama, fitrah dari sang pencipta, dari kedua hal tersebut tentunya akan terus tumbu dan berkembang secara beriringan dalam proses kehidupan di bumi. bersamanya pula akan terus lahir sistem-sistem peradaban maupun kebudayaan suatu masyarakat.

Namun diantara agama dan kehidupan memiliki sifat dasar yang berbeda. Agama memiliki sifat dasar "kepasrahan kepada tuhan", sedangkan kehidupan memilki sifat dasar kemandirian dan kearifan. Oleh karenanya pada setiap fase pertumbuhan berkebudayaannya akan banyak timbul gejala, variasi, irama yang berbeda-beda antara satu dengan lainnya.

Pada mulanya dirasa ada dominasi agama terhadap segala unsur bagi orangorang yang beragama, seperti dominasi hukum, hak asasi manusia, dan segala aspek kehidupan manusia termasuk di dalamnya adalah seni dan budaya. Hal ini tidak menjadi masalah jika sesuatu yang hadir dari agama adalah sesuatu yang dibenarkan dan tidak menjadi kepentingan-kepentingan yang bertentangan dengan agama.

Seiring dengan perkembangan pemikiran manusia, maka terlihat ada pergeseran pendominasian, terkadang pemikiran manusia lebih mendominasi melebihi normanorma agama. Hal ini menjadikan kehidupan manusia seperti kehilanga arah, dikarenakan sudah menjauhi norma-norma agama. Tak terlepas juga seni budaya yang berjalan tidak beriringan dengan nilai-nilai agama. Banyak juga ditemukan seni budaya yang lepas dari nilai-nilai agama bahkan sampai bertolak belakang dengan agama.

Pada realitas tersebut, pendidikan memiliki andil yang besar, terutama pendidikan agama Islam. Peran yang dilakukan pendidikan adalah mengisi kembali ruang-ruang yang kosong dalam dimensi kesenian dan kebudayaan, yang sudah jelas seni dan budaya adalah seuatu proses manusia untuk berperilaku baik antar umat beradab dan beragama terutama di Indonesia dengan beragam bahasa dan suku budaya.

Peran lain pendidikan agama Islam bagi seni budaya Islam adalah menciptakan penyadaran berkaitan pentingnya pencarian solusi atas normativitas dan historisitas pemikiran Islam yang berkaitan dengan seni budaya. Pendidikan agama Islam berperan untuk mencari solusi segala persoalan berkaitan dengan sikap repsesif atau 
pengekangan akan dunia seni dan budaya, di dalamnya mencakup pemikiran dan karyanya. Terkadang nilai-nilai seni budaya bersifat ideologis yang artinya final, tertutup dan cenderung normatif. Maka di sini masuk pendidikan dengan asumsi keilmuan yang membawa sifat keterbukaan, sosialis, dan faktual historis (Nasr, 1993).

Sudah waktunya lagi pendidikan agama Islam dibalut dengan seni dan budaya agar segala sesuatu yang sudah ada (warisan leluhur) tersebut tidak hanya menjadi cerita dan sejarah. Pendidikan yang terbalut dengan seni budaya akan menumbuhkan proses yang kreatif serta inovatif, terlebih pemaknaan akan nilai-nilai yang hendak disampaikan oleh seorang pendidik. misalnya kaitannya dengan penyampaian materi ajar, guna mencetak manusia-manusia yang memiliki akhlak baik, berbudi luhur, berkarakter serta mengamalkan nilai-nilai ajaran agama Islam dalam kehidupannya.

\section{Pendidik dalam Balutan Seni dan Budaya, Upaya Pengajaran PAI Bernilai Estetika}

Kehidupan manusia akan selalu berkembang dan bersifat dinamik, begitu juga dengan budayanya. Berdasarkan dinamika tersebut, cara penyampaian manusia dalam menata kehidupan akan sangat variaif. Pada dunia pendikan misalnya akan sangat erat kaitannya dengan metode belajar, strategi belajar dan lain sebagainya, demi tercapainya kesempurnaan dalam berkehidupan.

Berdasarkan sejarah yang diketahui bahwa walisongo berhasil menyebarkan ajaran agama Islam di Nusantara, salah satu metode yang dipakai yaitu melalui kesenian, oleh karenanya masyarakat secara perlahan mudah menerima ajaran-ajaran tersebut. Kesenian memiliki banyak unsur yang terkandung, seperti teks naskah, aktor, alur cerita, musik, simbol-simbol, bentuk fisik dan lain sebagainya.

Terdapat dua macam konsep dalam pendidikan seni, pertama, konsep pendidikan seni yang berkaitan dengan aspek ekspresi artistik, kedua pendidikan seni yang dikaitkan dengan tujuan pendidikan. Beberapa konsep pendidikan seni yang pernah ada di antaranya : gerakan reform, pendidikan seni untuk apresiasi, pendidikan seni untuk pebentukan konsepsi, pendidikan seni untuk pertumbuhan mental dan kreatifitas, seni sebagai keindahan, seni sebgai imitasi, dan seni sebagai hiburan (Sahuya, 2016).

Pendidik dalam proses pembelajaran bisa juga disebut dengan sang aktor, aktor adalah salah satu unsur permainan drama. Para aktor ini dituntut untuk menyajikan sesuatu yang bisa menghipnotis atau berkesan kepada penonton, penonton dalam 
konteks ini adalah anak didik. Apabila sang aktor mampu membawa penonton ke arah yang diinginkan maka dirasa proses itu berhasil. Melihat dari konsep pendidikan seni, dan sekaligus kedudukan pendidik sebagai aktor maka dirasa akan lahir beberapa langkah pembelajaran PAI yang variatif-inovaif di antaranya:

a. Konsep Gerakan reform

Gerakan reform akan mengutamakan kebebasan berekpresi sebagai cara untuk memberi peluang kepada peserta didik dalam mengembangkan kemampuan yang ada pada dirinya. Tujuannya adalah untuk mendewasakan peserta didik bukan secara intelektual saja, melainkan aktif dalam perbuatannya ataupun kesehariannya. Dengan mendapatkan pengalaman "pelajaran dari sesuatu yang dialaminya. Semisal contoh seorang guru membebaskan peserta didik untuk melakukan observasi terhadap kaum duafa, ataupun orang-orang yang diwajibkan menerima zakat. Dangan cara apapun dari hasil observasi akan dipresentasikan di depan kelas atau bentuk laporan lainnya. Secara langsung maupun tidak langsung peserta didik jika melakukan observasi akan menghayati kehidupan orang-orang penerima zakat.

b. Pendidikan Seni untuk Apresiasi

Dipelopori oleh Alfred Lichtwart dan Konrad Lange, dengan pemikiran bahwa persepsi seorang anak akan seni dan keindahan harus dikembangkan melalui penghayatan langsung. Didukung dengan observasi, kajian sejarah, library research dan lain sebainya. Dalam pembelaran PAI akan sangat sejalan jika peserta didik diarahkan dalam upaya pengkaryaan dalam bentuk apapun, bisa gambar, sayair, rupa, dan tentunya karya itu mengandung unsur kereligiusan.

c. Pendidikan Seni untuk Konsepsi

Bermula dari "pengungkapan pikiran” Walter Sargent, gambar adalah bahasa yang digunakan untuk melahirkan dan mengambangkan ide-ide yang ada di alam pikiran. Artinya mengungkapkan ekspresi ataupun persepsi kedalam bahasa visual, darinya kogmitif akan diuji dalam praktiknya.

Selain itu emosi seseorang akan digali, kecerdasan emosi dirasa penting sebab manusia tidak akan mampu mengungkap pengalaman secara mandiri dengan akal, sebab emosi mempunyai kepekaan terhadap kenyataan yang tak bisa ditangkap oleh akal. 
Pembelajaran PAI sangat bisa dilakukan dengan konsep tersebut, peserta didik diarahkan untuk menuangkan konsep pikiran yang ada pada fikirannya dalam bentuk bahasa visual. Semisal materi hari akhir, tidak menutup kemungkinan seseorang untuk membahasakannya dalam sifat visual.

d. Pendidikan Seni untuk Pertumbuhan Mental Kreatif

Pendidikan seni untuk pertumbukan mental reatif yang dimaksudkan adalah peserta didik adalah idealnya, sedangkan seni sarananya. Dalam artian seni adalah sarana bagi peserta didik dalam proses pertumbuhan mental jiwa terampil dan kreatif. Pendidikan seni budaya dan keterampilan sangatlah multilingual, multidimensional serta multi kultural.

Multilingual artinya yaitu pengembangan kemampuan untuk mengekpresikan diri secara kreatif, semisal dengan bahasa, rupa, gerak, bunyi dan lainnya. Multidimensional yakni pengembangan kompetensi, berupa konsepsi, apresiasi, dan kreasi, yaitu dengan memadukan secara harmonis unsur dari estetika, logika, kinestetika dan etika. Kemudian dimaksudkan multikultural adalah makna dari pendidikan seni sebagai kesadaran dan apresiasi terhadap budaya baik budaya lokal maupun mancanegara, dalam upaya pembentukan nilai demokratis serta toleran.

Seorang guru PAI bisa mengupayakan sarana-sarana penunjang pembelajaran yang sangat erat dengan nilai seni, sebagai upaya pembelajaran yang inovatif-kreatif serta meningkatkan kesadaran beragama.

e. Pendidikan Seni sebagai Keindahan

Dari konsep ini lahir bahasan bahwa seni akan selalu identik dengan keindahan, namun perlu dipahami bersama jika keindahan itu sendiri bersifat subjektif. Dengan segala upaya seorang guru dalam proses pembelajaran PAI pastinya tidak akan lepas dari unsur keindahan dan tentunya kenyamanan, jika pembelajaran itu nyaman maka dirasa akan indah. Seperti misalnya tata ruang belajar, konsep, desain lingkungan sekolah.

\section{f. Seni Sebagai Imitasi}

Seni sebagai imitasi adalah bentuk peniruan alam, dan segala bantuk seni maupun budaya haruslah tiruan dari alam. Pembelajaran akan sangat efektif jika itu adalah sebuah fenomena alam, akan mudah dilihat, dirasakan, dan bisa dianaisis. Dengan menyangkutpautkan alam di sekitar maka akan sangat efektif 
sebuah pembelajaran. Dalam pebelajaran PAI akan bisa dipadukan dengan metode belajar yang sifanya kembali pada alam, seperti latihan alam yang dilakukan para aktor teater, pecinta alam, pramuka dan lain sebagainya, pelatihan rasa akan dilakukan di alam, bisa berlokasi di gunung, laut, sungai, maka akan lebih dekat dengan sang pencipta.

Berbicara seni tidak akan ada habisnya, belum lagi ditambahkan dengan berbagai bentuk-bentuk senilainya, semisal musik. Musik sendiri merupakan alat komunikasi yang dapat menciptakan suasana hati bagi yang memainkan maupun yang mendengarkan. Gershwin dalam bukunya Yeni Rachmawati mengemukakan bahwa musik dapat menimbulkan getaran-getaran tertentu yang dapat disangkal lagi menimbulkan reaksi fisik, musik juga dapat meningkatkan matabolisme tubuh, mengubah kegiatan otot, mempengaruhi pernapasan, tekanan darah, meningkatkan aspek fisiologis untuk menghasilkan emosi yang berbeda-beda (Rachmawati, 2009).

Dari hal tersebut bisa dilihat suasana hati seseorang berdampak pada perilakunya, sedangkan suasana hati dibangun salah satunya melalui musik. Terhusus suasana hati ketika berada di tengah-tengah proses pembelajaran, maka perilakunya bisa terlihat dengan jelas. Seorang pendidik ataupun seorang aktor akan sangat bergantung pada kondisi emosionalnya, pun sama dengan anak didik, akan lebih mudah jika hati dan pikirannya sudah tertata dengan jernih dan suka cita.

Muhammad' Athiyyah al-Abrosyi mengutip dari Nur Saidah berpendapat, bahwa mengajarkan seni terkhusus syair-syair ataupun puisi menjadi sangat berguna untuk pembentukan akhlak dan perilaku anak didik (Saidah, 2008). Tentunya syair-syair itu berupa karya seni sastra yang bernuansakan akhlaqul karimah. Darinya anak didik bisa merasakan keindahan-keindahan syair berikut maknanya apalagi jika ditambahkan unsur-unsur lainnya seperti rupa, musik, simbol-simbol dan lain sebagainya. Kemudian dari penggabungan tersebut akan berpengaruh pada rasa, jiwa bahkan perilaku seseorang, di dalamnya termasuk orang yang sedang mencari ilmu.

Banyak penyair-penyair muslim yang sangat berpengaruh dalam seni sastra Islam yang membawa seni Islam semakin dikenal seperti Rumi, Athtahr, Hamzah Fanzuri dan walisongo, dari merekalah lahir syair-syair sastra yang sarat akan makna ketuhanan, kemanusiaan, keindahan dan nilailainnya. Dari kesemuanya merupakan salah satu proses dari pendidikan agama Islam. 
Ditarik pada konteks yang lebih luas, kesenian ataupun berksesenian sangat berharga di dalam tingkah laku manusia, terlebih dalam seni mengajar bagi pendidik. Artinya seseorang yang paham dan mengamalkan nilai kesenian di setiap unsur kehidupannya akan lebih cenderung peka terhadap sekitar, baik kepada sesama mahluk hidup dan kepada sesuatu yang tidak hidup. Kecenderungan bisa berupa ekspresi-ekspresi yang tertuang dalam bentuk perilaku maupun karya-karya, mudah bergaul dengan yang lainnya. Maka kondisi tersebut sangat erat kaitannya dengan proses belajar mengajar yang seharusnya memilik nilai kreativitas yang bervariasi.

Nilai kesenian dalam proses pembelajaran dapat dilakukan dengan dua hal yaitu kontek dan konten. Kontek berupa kemeriahan lingkungan belajar, yang dapat disiapkan dengan cara merekayasa suasana dan emosi anak didik, membangun landasan materi dengan kuat, dan juga menciptakan suasana belajar yang variatif, dan mengintegrasikan materi ajar dengan kehidupan sehari-hari berdasarkan pengalaman. Sedangkan konten berupa kekayaan materi yang akan disampaikan dari seorang pendidik. Dengan menyiapkan presentasi, fasilitas yang menunjang (Saidah, 2008).

Pengembangan seni budaya dalam Pendidikan agama Islam bisa dilakukan dengan cara mengadakan kegiatan belajar mengajar dengan mengedepankan rasa, yaitu dengan pendidikan nilai etis dan estetis. Pendidikan etis sendiri mengembangkan perasaan anak didik baik rasa religiusitas, rasa sosial, pribadi dan lain sebagainya, sedangkan pendidikan estetis dengan cara menghaluskan perasaan melalui rasa estetis.

Nilai etis dan estetis salah satunya akan ditemukan di dalam permainan tradisonal, sebut saja permainan Gobak Sodor, Betengan, dan masih banyak lainnya. Permainan tradisional tersebut adalah gabungan dari permainan, seni suara, gerak, gambar/visual. Jika ambil manfaatnya: seni yang diambil dari suara yang bisa ditangkap telinga kemudian masuk dalam kalbu kemudian akan membentuk kepribadian ataupun watak. Seni gerak akan bermanfaat bagi perkembangan karsa, kemudian seni yang terlihat akan merangsang tumbuh kembangnya syaraf otak dan mempengaruhi kecerdasar berfikir.

Selain kesenian tradisional, masih banyak kesenian-kesenian bernilai estetis yang mampu menopang cara, dan strategi pembelajaran, terhusus bagi pembelajaran PAI yang syarat akan makna, nilai-nilai, bahkan pedoman hidup. Maka dari itu alangkah 
baiknya seorang pendidik mampu memahami serta mengamalkan seni serta budaya agar nilai luhur suatu peradaban yang baik akan terus terjaga dan berkembang.

\section{SIMPULAN DAN SARAN}

\section{Simpulan}

Pendidikan dan seni budaya tidak akan pernah bisa dilepaskan karena keduanya memiki korelasi dan kontribusi yang kuat, baik kontribusi seni budaya untuk pendidikan maupun kontribusi pendidikan untuk lahirnya sebuah seni budaya. Budaya sendiri dibentuk dari hasil interaksi sosial masyarakat, di dalamnya mencakup pendidikan. Artinya seni budaya juga merupakan dasar terbentuknya kepribadian manusia. Sama halnya dengan pendidikan yang membentuk karakter maupun kepribadian seseorang, terlebih pendidikan agama Islam.

Dari korelasi dan kontribusi antara pendidikan dan seni budaya, sudah sepatutnya pembelajaran PAI membawa unsur seni dan budaya, guna memperlancarkan proses pembelajaran, semisal dengan mengembangkan konsep gerakan reform, pendidikan seni untuk apresiasi, konsep peMbentukan konsepsi, pertumbuhan mental dan kreatifitas, seni sebagai keindahan, dan seni sebagai imitasi.

Apresiasi yang baik terhadap seni akan menjadikan seseorang peka terhadap nilai-nilai ketuhanan, nilai-niai kemanusiaan, serta nilai-nilai lainnya baik yang kasat mata maupun tidak kasat mata. Darinya proses pembelajaran PAI akan lebih kreatif, inovatif, indah dan menyenangkan, dikarenakan pembelajaran PAI tersebut bernilai estetik, tentunya tidak luput dari tujuan yang hendak dicapai dari pendidikan agama Islam itu sendiri.

\section{Saran}

Berkaitan dengan hasil pembahasan, diharapkan kepada pendidik untuk bisa mewarna pembelajaran pendidikan agama Islam dengan seni dan budaya, di mana di dalam seni dan budaya banyak memiliki nilai maupun makna serta bisa menjadi terobosan sebagai inovasi kreatif seorang pendidik. Diharapkan kepada pengelola lembaga pendidikan untuk senantiasa menjaga tradisi yang baik, terlebih seni dan budaya lokal, selain menjadi jalan alternatif di dalam dunia pendidikan juga akan melestarikan seni dan budaya. 


\section{DAFTAR PUSTAKA}

Abdul Majid (2012), Belajar dan Pembelajaran Pendidikan Agama Islam, Bandung: Remaja Rosdakarya.

Dian Nur Ana (2018), Seni dan Agama dalam Islam, Yogyakarta: Bildung.

Eka Titi Andrayani (2016), "Proses Terjadinya Suatu Karya Seni”, Jurnal Imaji Vol. 12 Nomor 2, ISSN 2580-0175.

Ensiklopedia Nasional Indonesia (1989), Jakarta: PT Cipta Adi Pustaka.

H.A.R Tilaar (2002), Pendidikan, Kebudayaan, dan Masyarakat Madani Indonesia. Bandung: Remaja Rosda Karya.

Heri Gunawan (2014), Pendidikan Islam, Kajian Teoritis dan Pemikiran Tokoh. Bandung: PT Remaja Rosdakarya.

John Felix (2012), "Pengertian Seni Sebagai Pengantar Kuliah Sejarah Seni Rupa", Jurnal Humaniora Vol. 3 Nomor. 2, Oktober, 614-621.

Kartika, D. S (2004), Pengantar Estetika, Bandung : Rekayasa Sains.

Muhaimin dan Suti'ah (2002), Paradigma Pendidikan Islam; Upayamengefektifkan Pendidikan Agama Islam Di Sekolah, Bandung: Remaja Rosdakarya.

Nur Saidah, (2008), "Pendidikan Agama Islam dan Pengembangan Seni Budaya Islam". Jurnal Pendidikan Agama Islam, Vol. V, Nomor. 1.

Oliver Leaman (2005), Estetika Islam, Manafsirkan Seni dan Keindahan, terjemah Irfan Abubakar, Islamic aesthetics, Bandung: Mizan.

Seyyed Hossein Nasr (1993), Spiritualitas dan Seni Islam, Bandung: Mizan.

Sindhunata (2000), Membuka Masa Depan Anak-anak Kita: Mencari Kurikulum Pendidikan Abad XXI. Yogyakarta: Kanisius.

Suhaya (2016), "Pendidikan Seni Sebagai Penunjang Kreatifitas”, Jurnal pendidikan dan Kajian Seni, Vol. 1 Nomor. 1, Apri, ISSN 2503-4626.

Yeni Rachmawati (2005), Musik Sebagai Pembentuk Budi Pekerti-Sebuah Panduan Untuk Pendidikan. Yogyakarta: Jalasutra. 